University for Business and Technology in Kosovo

UBT Knowledge Center

UBT International Conference

2018 UBT International Conference

Oct 27th, 3:15 PM - 4:45 PM

\title{
The Importance of CAD/CAE systems in development of Product Design and Process of Optimization
}

\author{
Fatmir Azemi \\ University for Business and Technology, fatmir.azemi@ubt-uni.net \\ Xhemajl Mehmeti \\ University for Business and Technology, xhemajl.mehmeti@ubt-uni.net \\ Bekim Maloku \\ SHMT "Lutfi Musiqi", bekim.m70@hotmail.com
}

Follow this and additional works at: https://knowledgecenter.ubt-uni.net/conference

Part of the Robotics Commons

\section{Recommended Citation}

Azemi, Fatmir; Mehmeti, Xhemajl; and Maloku, Bekim, "The Importance of CAD/CAE systems in development of Product Design and Process of Optimization" (2018). UBT International Conference. 344. https://knowledgecenter.ubt-uni.net/conference/2018/all-events/344

This Event is brought to you for free and open access by the Publication and Journals at UBT Knowledge Center. It has been accepted for inclusion in UBT International Conference by an authorized administrator of UBT Knowledge Center. For more information, please contact knowledge.center@ubt-uni.net. 


\title{
The Importance of CAD/CAE systems in development of Product Design and Process of Optimization
}

\author{
Fatmir Azemi ${ }^{1}$, Xhemajl Mehmeti ${ }^{2}$, Bekim Maloku ${ }^{3}$ \\ ${ }^{1}$ UBT - Higher Education Institution, Lagjja Kalabria, 10000 p.n., Prishtinë, Kosovë \\ fatmir.azemi@ubt-uni.net \\ ${ }^{2}$ UBT - Higher Education Institution, Lagjja Kalabria, 10000 p.n., Prishtinë, Kosovë \\ xhemajl.mehmeti@ubt-uni.net \\ ${ }^{3}$ SHMT”Lutfi Musiqi” Vushtrri, Rr. "Kruja”, 42000 p.n., Vushtrri, Kosovë \\ bekim.m70@hotmail.com
}

\begin{abstract}
Computer Aided Design (CAD) and Computer Aided Engineering (CAE) are the most important technology tools that today designers are using in development of product (design and in process of optimization). Thus, this study is carried out to present the importance of CAD/CAE system on process of design and process of optimization of spur gear. The paper presents the usage of CAD system for modeling parts and CAE software for analysis of stress-strain of spur gear and the results of calculation of pair spur-gears that it used in the gearbox transmission of the bucket wheel excavator located in "Bardhi i Madh - Fushë Kosovë", and after that will be optimized the shape of the spur gear with usage of ANSYS software. Consequently, the aim of this research is to calculate stress-strain structure of parts (gears) and reduce weigh of the gears.
\end{abstract}

Keywords: CAD/CAE, spur gear, product design, stress-strain analysis, process of optimization 


\section{Introduction}

As it knows, in the past, for verification design of product needed physical prototype testing. Results came from making of prototype, loading it with forces, taking results and then on engineering judgement make changes based on the results. Today, demands of costumers are more complex, initiatives like continuous cost improvement and quality of product in shorter time have put greater demands on product performance, and as a results, required innovative design and engineering. The radical change of technology in today world market, product innovation is a key factor for success across nearly all industries. The aim is to make a new class of products in order to be competitive. Most companies are working in innovative design products through a combination of technology, process and people to translate knowledge of customer requirement into variable products. If companies want to stay in business competitive they must know their customers, develop ideas based on engineering fundamentals and use computer based tools such as CAD [1], CAE [2], etc., to develop and refine designs accurately and quickly as much as possible [3]. Computer Aided Design (CAD) and Computer Aided Engineering (CAE) are tools of recent technology that assist in engineering processes such as creation, design, simulation, analysis, optimization and modifications, and so on [4]. It is an integration of Mechanical and Computer Technology to aid in the design process like Modeling, Assembly, Drafting, Die Design, Tool Design, Sheet metal, analysis of products etc. In this paper we have used CATIA software as CAD software for modeling of spur gears as well as their assembly, Inventor and ANSYS Workbench 14.0 software for stress-strain analysis and process of optimization. In our case a real case study is used for Stress-Strain Analysis of the spur gear of the gearbox transmission (gear-box reduction) of the working wheel of Excavator.

\section{Statement of the problem, objectives and purpose of the study}

The real case study has been draw from gear transmission (gear-box reduction) of the excavator which is located in open-cast coal mines in Kosovo mines, and during Excavator arm movement from right side to left the bucket wheel works with maximum capacity and in that case have been caused damage in spur gear 9 and spur gear 10 of gear- box reduction of the Excavator. Objective and purpose is to determine stress-strain structure of spur gear 9 and spur gear 10 with CAD and CAE system in order to find out if the gears accomplish working conditions, which factors aren't fulfilling conditions and finding a solution and optimization of the spur gear. Figure 1 shows type of the excavator. 


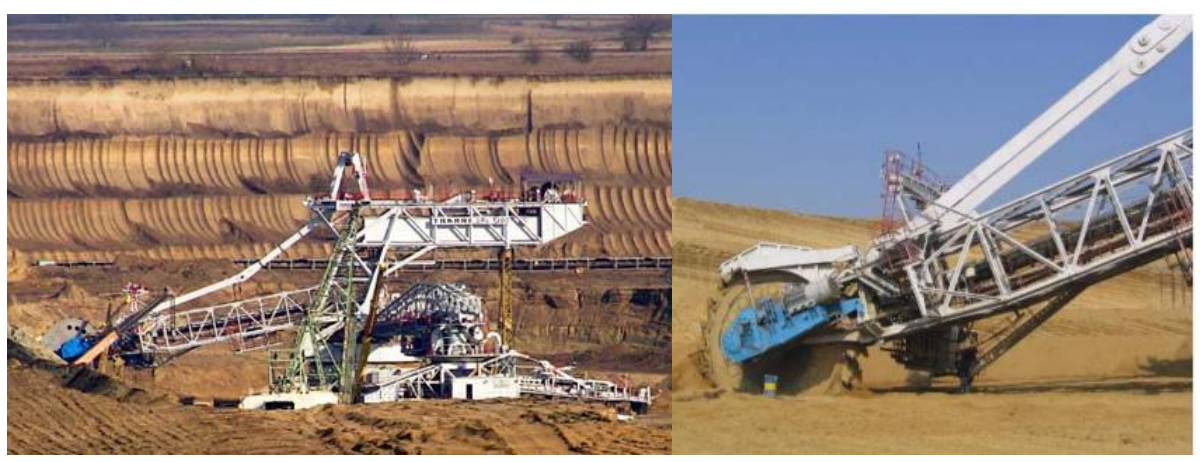

Fig.1. Type of Excavator SRs 1300 and working wheel

\subsection{Determination of working loads in gear transmission of bucket wheel of Excavator with measurement}

Based on the conditions and characteristics of the operating environment in terrain bucket wheel of excavators are produced as unique and are supposed to excavate coal. Bucket wheel excavators are produced mostly as unique products according to the conditions and characteristics of the operating environment where they are supposed to excavate coal or ore (Fig.1).

Excavating process is periodical, because excavating material realized by bucket cyclin during entering and exiting and have in mind that material of coal (lignite in this case) isn't homogenize, determination of torque on the output shaft through mathematical formula is near impossible. Therefore, tenzometrike measurements socalled Winston bridge method of deformation has been done [5], figure 2 .

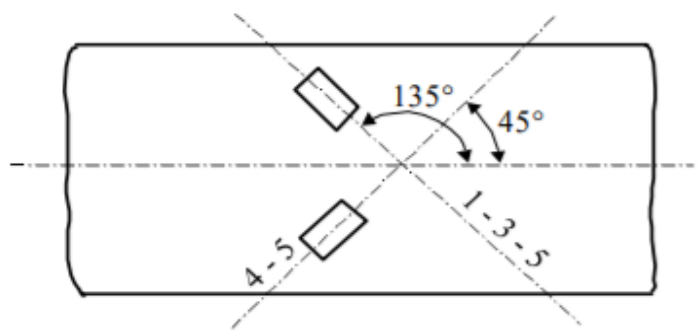

Fig.2. Winston bridge method for measurement deformation

Based on this method has been calculated the value of torque as a main parameter for calculus of all other parameters of the gearbox transmission.

Tangential deformations have calculated as follows:

$$
\tau_{x y}=\frac{E\left(\varepsilon_{45}-\varepsilon_{135}\right)}{2(1+\mu)}=\frac{E \cdot \varepsilon}{2 \cdot(1-\mu)}
$$


Where are:

$\mathrm{E}$ - module of elasticity for material of shaft, $\varepsilon 45,135$ - relative deformation in the directions, $\mu$ - Poisson's coefficient,

The torque on working wheel $\mathrm{T}$ which is required for further calculation for elements of gearbox transmission and in our case for design of spur gear and shape optimization of it is:

$$
T=\frac{E}{1+\mu} \cdot W_{0} \cdot \varepsilon
$$

$W_{0}$ - polar moment of resistance of the cross section.

Based from equations (1), (2) and from diagram of oscilogram (fig.3) measuring the deformation in the shaft during work of bucket wheel are achieved value of the torque $T$ as below [5]:

- from 3899 to 4260 [Nm] - at the time of starting work of Excavator, - from 2635 to 4729 [Nm] - at the maximum capacity of Excavator.

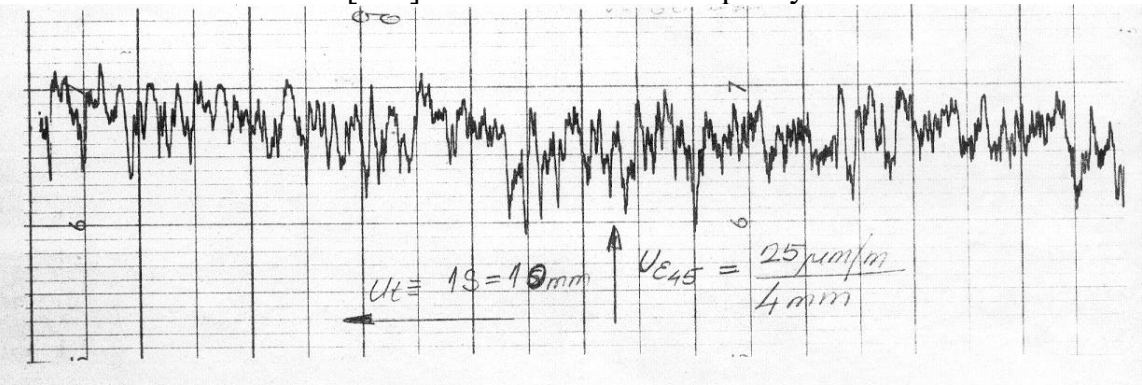

Fig.3. Oscilogram measuring the deformation in the shaft during working of bucket wheel

Based on the calculation of gear box the torques on the gear 9 and gear 10 are [6]:

$$
T_{9}=195635.282[\mathrm{~N} \cdot \mathrm{m}] \text { and } T_{10}=1070451.049[\mathrm{~N} \cdot \mathrm{m}]
$$

\section{Method and Materials}

Computer Aided Design tools are used for the creation of 3D solid or surface models, or $2 \mathrm{D}$ drawings of physical components. There are many CAD environments available for creating new engineering designs or concepts. As a new design or modification to a current design is developed in a package such as CATIA or Autodesk Inventor, the model can then be created in a short time to have an actual prototype for further testing. This prototype, along with analysis tools, helps to quickly define the success and failures of the new design [7]. 
In this case we have used CATIA V5, Autodesk Inventor Professional and ANSYS software for design, analysis and shape optimization of parts and their assembly.

This design of parts has been done in CATIA Software and will be used for analyses of stress-strain structure of assembly with the application Finite Element Method. Ansys Workbench 14.0 is used for analyses, design of assembly has been imported from CATIA saved as IGES file to ANSYS software for analyses [8],[9] figure 4.

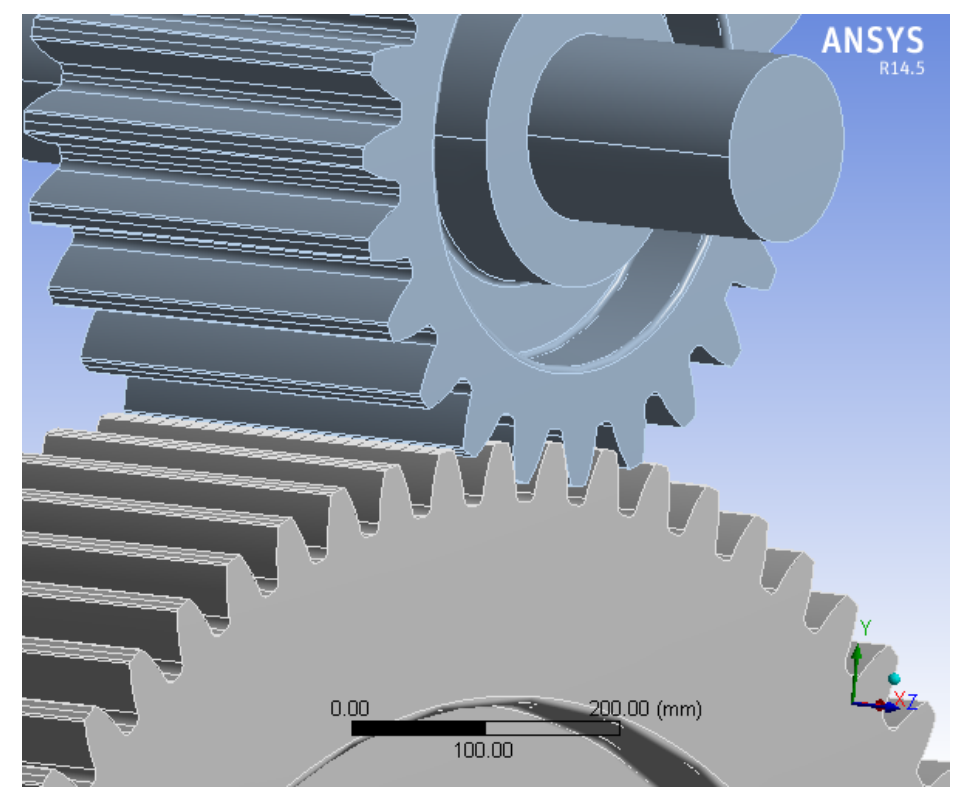

Fig.4. Assembly parts opened in ANSYS WORKBENCH 14.0

\subsection{Data materials and parameters of assembly}

Autodesk Inventor professional 2015, Spur Gears Component Generator is used to generate a pair of gears with same geometry and material as shown below on tables. Method of Strength Calculation based on ISO 6336:1996.

Parameters, geometrical data, materials and loads are given through tables as below [10]:

Table 1. Common parameters of assembly (parts)

\begin{tabular}{llc}
\hline Gear Ratio & $\mathrm{i}$ & $5.5833 \mathrm{ul}$ \\
\hline Desired Gear Ratio & $\mathrm{i}_{\text {in }}$ & $5.5833 \mathrm{ul}$ \\
Module & $\mathrm{m}$ & $20.000 \mathrm{~mm}$ \\
Helix Angle & $\beta$ & $0.0000 \mathrm{deg}$ \\
Pressure Angle & $\alpha$ & $20.0000 \mathrm{deg}$ \\
Center Distance & $\mathrm{a}_{\mathrm{w}}$ & $1600.000 \mathrm{~mm}$ \\
Product Center Distance & $\mathrm{a}$ & $1580.000 \mathrm{~mm}$ \\
\hline
\end{tabular}




\begin{tabular}{llc}
\hline Total Unit Correction & $\Sigma \mathrm{x}$ & $1.0458 \mathrm{ul}$ \\
Circular Pitch & $\mathrm{p}$ & $62.832 \mathrm{~mm}$ \\
Base Circular Pitch & $\mathrm{p}_{\mathrm{tb}}$ & $59.043 \mathrm{~mm}$ \\
Operating Pressure Angle & $\alpha_{\mathrm{w}}$ & $21.8831 \mathrm{deg}$ \\
Contact Ratio & $\varepsilon$ & $1.4226 \mathrm{ul}$ \\
Limit Deviation of Axis Parallelity & $\mathrm{f}_{\mathrm{x}}$ & $0.0290 \mathrm{~mm}$ \\
Limit Deviation of Axis Parallelity & $\mathrm{f}_{\mathrm{y}}$ & $0.0140 \mathrm{~mm}$ \\
\hline
\end{tabular}

Table 2. Main geometric data of gears

\begin{tabular}{llcc}
\hline & & Gear 9 & Gear 10 \\
\hline Type of model & & Component & Component \\
Number of Teeth & $\mathrm{z}$ & $24 \mathrm{ul}$ & $134 \mathrm{ul}$ \\
Unit Correction & $\mathrm{x}$ & $0.8869 \mathrm{ul}$ & $0.1589 \mathrm{ul}$ \\
Pitch Diameter & $\mathrm{d}$ & $480.000 \mathrm{~mm}$ & $2680.000 \mathrm{~mm}$ \\
Outside Diameter & $\mathrm{d}_{\mathrm{a}}$ & $553.646 \mathrm{~mm}$ & $2724.522 \mathrm{~mm}$ \\
Root Diameter & $\mathrm{d}_{\mathrm{f}}$ & $465.478 \mathrm{~mm}$ & $2636.354 \mathrm{~mm}$ \\
Base Circle Diameter & $\mathrm{d}_{\mathrm{b}}$ & $451.052 \mathrm{~mm}$ & $2518.376 \mathrm{~mm}$ \\
Work Pitch Diameter & $\mathrm{d}_{\mathrm{w}}$ & $486.076 \mathrm{~mm}$ & $2713.924 \mathrm{~mm}$ \\
Facewidth & $\mathrm{b}$ & $640.000 \mathrm{~mm}$ & $640.000 \mathrm{~mm}$ \\
Facewidth Ratio & $\mathrm{b}_{\mathrm{r}}$ & $1.33 \mathrm{ul}$ & $0.2388 \mathrm{ul}$ \\
\hline
\end{tabular}

Table 3. Materials of spur gears

\begin{tabular}{llcc}
\hline & & Gear 9 & Gear 10 \\
\hline Ultimate Tensile Strength & $\mathrm{S}_{\mathrm{u}}$ & User material & User material \\
Yield Strength & $\mathrm{S}_{\mathrm{y}}$ & $700 \mathrm{MPa}$ & $700 \mathrm{MPa}$ \\
Modulus of Elasticity & $\mathrm{E}$ & $206000 \mathrm{MPa}$ & $340 \mathrm{MPa}$ \\
Poisson's Ratio & $\mu$ & $0.300 \mathrm{ul}$ & $206000 \mathrm{MPa}$ \\
Bending Fatigue Limit & $\sigma \mathrm{Flim}$ & $421.0 \mathrm{MPa}$ & $490.0 \mathrm{MPa}$ \\
Contact Fatigue Limit & $\sigma_{\mathrm{Hlim}}$ & $1195.0 \mathrm{MPa}$ & $1370.0 \mathrm{MPa}$ \\
Hardness in Tooth Core & $\mathrm{JHV}$ & $210 \mathrm{ul}$ & $210 \mathrm{ul}$ \\
Hardness in Tooth Side & VHV & $600 \mathrm{ul}$ & $600 \mathrm{ul}$ \\
\hline
\end{tabular}

Table 4. Loads

\begin{tabular}{lccc}
\hline & & Gear 9 & Gear 10 \\
\hline Power & $\mathrm{P}$ & $676.067 \mathrm{~kW}$ & $662.546 \mathrm{~kW}$ \\
Speed & $\mathrm{n}$ & $33.00 \mathrm{rpm}$ & $5.91 \mathrm{rpm}$ \\
& & $195635.282 \mathrm{~N} \mathrm{~m}$ & \multicolumn{2}{c}{$1070451.049 \mathrm{~N} \mathrm{~m}$} \\
Torque & $\mathrm{T}$ & & $0.980 \mathrm{ul}$ \\
Efficiency & $\eta$ & $323314.557 \mathrm{~N}$ \\
Radial Force & $\mathrm{F}_{\mathrm{r}}$ & & $804957.669 \mathrm{~N}$ \\
Tangential Force & $\mathrm{F}_{\mathrm{t}}$ & & $0.000 \mathrm{~N}$ \\
Axial Force & $\mathrm{F}_{\mathrm{a}}$ & & $867461.326 \mathrm{~N}$ \\
Normal Force & $\mathrm{F}_{\mathrm{n}}$ & & \\
\hline
\end{tabular}




\section{Results and Discussion}

With the usage of CAD and CAE software we can read that the minimum of stress is $0.0027365 \mathrm{MPa}$ and maximum stress is $662.33 \mathrm{MPa}$, whereas the minimum of Equivalent Elastic Strain is $2.4689 \mathrm{e}-008 \mathrm{~mm} / \mathrm{mm}$ and the maximum of Equivalent Elastic Strain is $0.0038289 \mathrm{~mm} / \mathrm{mm} 0.0027365 \mathrm{MPa}$ and maximum of stress is 662.33 $\mathrm{MPa}$. Graphically are presented in figure 5.

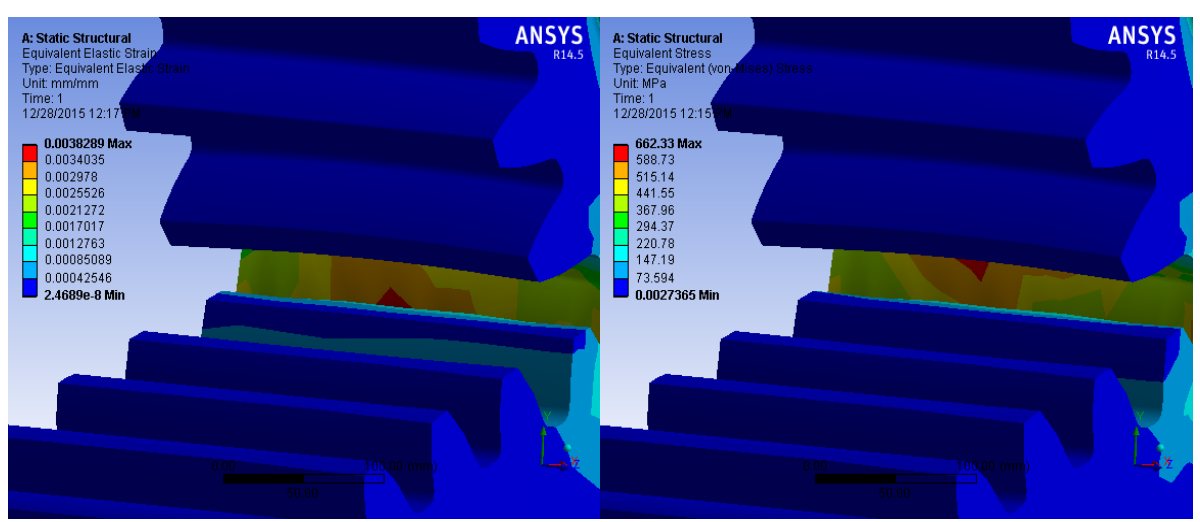

Fig.5. Static structural of Stress-Strain

After the analyses of Stress-Strain of gears, the gears (pinion and gear) are calculated in Inventor, the tools Spur Gears Component Generator has created components after application method of "Type of Strength Calculation-Material Design". Results are given on tables as below.

Table 5. Results after analyses of Stress-strain

\begin{tabular}{llcc}
\hline & & Gear 1 & Gear 2 \\
\hline & & User material & User material \\
Ultimate Tensile Strength & Su & $700 \mathrm{MPa}$ & $700 \mathrm{MPa}$ \\
Yield Strength & $\mathrm{Sy}$ & $340 \mathrm{MPa}$ & $340 \mathrm{MPa}$ \\
Modulus of Elasticity & $\mathrm{E}$ & $206000 \mathrm{MPa}$ & $206000 \mathrm{MPa}$ \\
Poisson's Ratio & $\mu$ & $0.300 \mathrm{ul}$ & $0.300 \mathrm{ul}$ \\
Bending Fatigue Limit & $\sigma \mathrm{Flim}$ & $604.5 \mathrm{MPa}$ & $623.8 \mathrm{MPa}$ \\
Contact Fatigue Limit & $\sigma \mathrm{Hlim}$ & $1331.4 \mathrm{MPa}$ & $1121.6 \mathrm{MPa}$ \\
Hardness in Tooth Core & JHV & $210 \mathrm{ul}$ & $210 \mathrm{ul}$ \\
Type of Treatment & type & $2 \mathrm{ul}$ & $2 \mathrm{ul}$ \\
Factor of Safety from Pitting & SH & $2.138 \mathrm{ul}$ & $2.138 \mathrm{ul}$ \\
Factor of Safety from Tooth & SF & $8.248 \mathrm{ul}$ & $7.659 \mathrm{ul}$ \\
Breakage & & & \\
Static Safety in Contact & SHst & $1.204 \mathrm{ul}$ & $1.204 \mathrm{ul}$ \\
Static Safety in Bending & SFst & $19.181 \mathrm{ul}$ & $17.894 \mathrm{ul}$ \\
Check Calculation & & Positive & \\
\hline
\end{tabular}


ANSYS WORKBENCH Software has been used for analysis and shape optimization of spur gear with Finite Element Method[11].

Figure 6 shows that area with red color are parts which should be removed for shape optimization.

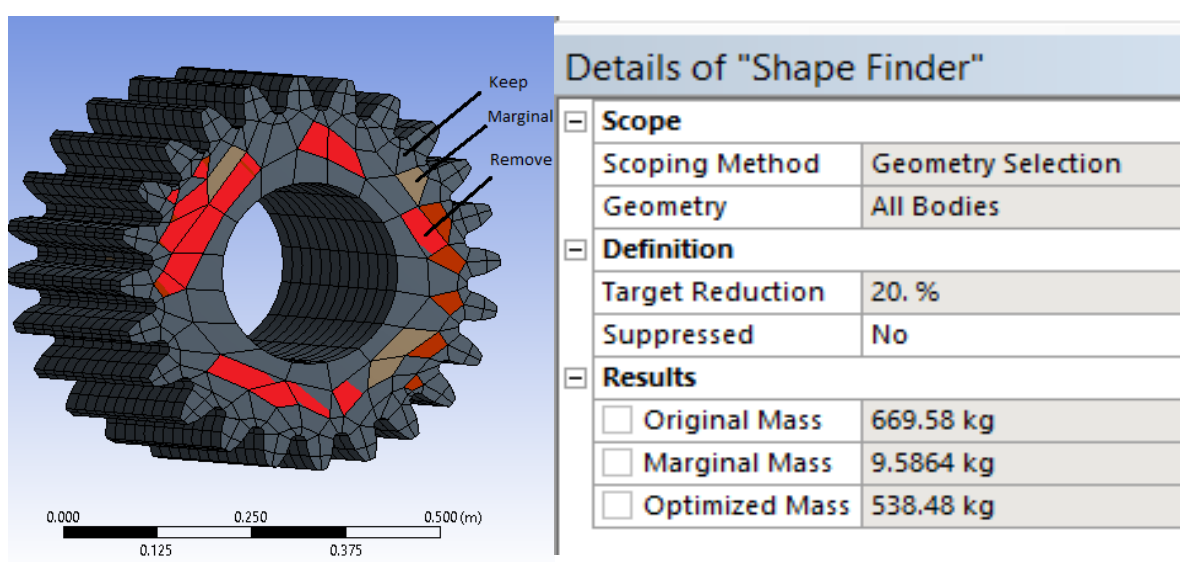

Fig.6. Shape optimization of spur gear in ANSYS software and mass reduction

\section{Conclusion}

This paper has presents the importance of CAD and CAE in process of product development. Are many components that indicating in product development, such as calculations, design, material strength, manufacturing quality and etc. First, has been used CAD software for designing parts and their assembly in order to import files to CAE software for analysis of stress-strain structure. After that, analyses shown that the material and dimensions that have been used for making gears are not fulfilling conditions in case when Excavator works with maximum capacity. It can be concluded that for fulfilling conditions needed to change the material of gears or should be increased dimensions. In this paper geometry integration of the spur gear is used in order for relational design to be successfully implemented, all parts and products need to be parameterized. The spur gears geometry can be generated using mathematical calculations done in Autodesk Inventor professional and CATIA supports parametric design, through which gear geometry formula and relations are created. The model of spur gear 9 has been exported in ANSYS software for shape optimization. The design optimization helps in reducing $20.5 \%$ of the structure weight (the initial and final mass of the spur gear are $669.58 \mathrm{~kg}$ and $538.48 \mathrm{~kg}$, respectively), which in turn reduces the cost of the spur gear with safe design.

Use of $\mathrm{CAD} / \mathrm{CAE}$ also helps to create the better innovations in the product. By integrating analysis and process of design in development of product at the earlier stages the productivity can be enhanced and could be obtained superior designs. 


\section{References}

[1] R. W. Kennard and L. A. Stone, "Computer Aided Design of Experiments," Technometrics, 1969.

[2] E. H. Dill, The finite element method for mechanics of solids with ANSYS applications. 2012.

[3] V. Mahesh, "Role of Computer Aided Design and Engineering in Product Development," in Conference: International Conference on Advanced Materials, Manufacturing, Management, Thermal science, 2013, p. 6.

[4] M. M. Cappiello et al., "NIH Public Access," J. Ethnopharmacol., 2011.

[5] B. Hamidi and B. Bislimi, "Analysis Experimental Constraint and Deformation in the Axis of Reductor of the Rotor Excavation," in 16th International Research/Expert Conference "Trends in the Development of Machinery and Associated Technology" TMT 2012, Dubai, UAE, 10-12 September 2012, 2012, pp. 631-634.

[6] F. Azemi, G. Pllana, M. Turbunja, and B. Maloku, "Stress-Strain Analysis of the Spur Gear-Box reduction of the Working Wheel of the Excavator Using CAD/CAE software," Int. J. Mech. Prod. Eng. ISSN 2320-2092, vol. 4, no. 5, pp. 24-28, 2016.

[7] X. Zhou, Y. Qiu, G. Hua, H. Wang, and X. Ruan, "A feasible approach to the integration of CAD and CAPP," CAD Comput. Aided Des., 2007.

[8] P. Meghashyam, S. G. Naidu, and N. S. Baba, "Design and Analysis of Wheel Rim using CATIA \& ANSYS," Int. J. Appl. Innov. Eng. Manag., 2013.

[9] A. Menon and D. K. L. Lawrence, "Structural Optimization Using Ansys and Regulated Multiquadric Response Surface Model," Mech. Eng., 2005.

[10] F. Azemi, M. Terbunja, and B. Maloku, "A Review On Design, Analysis And Shape Optimization Of Spur Gears Of The Gear-Box Reduction Of The Working Wheel Of The Excavator SCHRS 1300 24/5.0 Using CAD/CAE Software," Int. J. Mech. Prod. Eng., vol. 4, no. 7, pp. 19-23, 2016.

[11] E. Villarreal et al., "ANSYS Modeling and Meshing Guide," Int. J. Mod. Eng. Res. ..., 2013. 